\title{
Near-Synonyms Within the Same Qur'anic Verse: A Contrastive English-Arabic Lexical Analysis
}

\author{
Linda Al-Abbas ${ }^{1} \&$ Rajai Al-Khanji ${ }^{1}$ \\ ${ }^{1}$ Department of Linguistics, University of Jordan, Jordan \\ Correspondence: Linda S Al-Abbas, Department of English Language and Literature, University of Jordan, \\ Amman, Jordan. E-mail: lindaalabbas_84@yahoo.com
}

Received: August 1, 2019 Accepted: August 26, 2019 Online Published: October 13, 2019

doi:10.5539/ijel.v9n6p125 URL: https://doi.org/10.5539/ijel.v9n6p125

\begin{abstract}
The Holy Qur'an has features that are difficult for translators to transfer into another language, and they face problems in conveying the different shades of meaning of the verses. From a wide variety of these problems is synonymy. Synonymy refers to words that mean the same or show semantic resemblance to one another. This study examines the translation of two root-sharing synonymous Arabic words, namely اسطاع and five well-known English translations. These include Pickthall (1930), Ali (1982), Arberry (1996), Abdel Haleem (2004), and Al-Hilali and Khan (2018). These translations are selected because they are popular in the Muslim World in addition to the fact that the translators belong to different linguistic, religious and cultural backgrounds. The analysis shows that the translators were inconsistent in their selections of the English equivalents for the words under study. Furthermore, they did not convey the slight differences between the words and translated them similarly and interchangeably. The study concludes that some Qur'anic words are untranslatable, and cannot be rendered into another language, and therefore, translators are recommended to include explanatory notes between brackets or as footnotes in order to acknowledge the non-Arab readers that repetition of the words was not haphazard but intended for specific purposes.
\end{abstract}

Keywords: Arabic Language, Qur'an, Near-Synonymy, translation

\section{Introduction}

Although linguists do not have a good answer to the question of how to define the notion of what a word is, in a clear and consistent way, semanticists agree that words are the smallest meaningful units of speech that can stand by themselves. Words connect forms to the appropriate objects or concepts in the world to establish their lexical meanings, and are stored in the human memory with information about pronunciation, syntactic characteristics, and so on (Carroll, 1998). This inventory of words is known as the mental lexicon and is said to be a combination of our knowledge of words and our knowledge of the world (Murphy, 2010). However, language is not only about words. People communicate through larger pieces of discourse which are formed when words are productively connected to one another to produce phrases and sentences. These novel sentences are understood by putting together the meanings of each word. However, words usually occur in different contexts whose influence is crucial to determine their meanings. All this lies at the heart of a subfield of semantics known as lexical semantics. It can be defined as that branch of semantics that deals with sense relations (Lyons, 1977). There are fundamental issues that lexical semanticists investigate among which are how to describe the meanings of words in the language, and how to account for the variation of meaning in different contexts (Paradis, 2012). These two areas are interconnected, since an adequate description of meaning must account for the contextual variation and how we interpret it.

Moreover, the meaning of a word is defined in part by its relation to other words in language. These relations play a significant role in creating a coherent discourse by using related words, thus, providing different information and avoiding repetition. Among these relations is synonymy.

Synonymy is equivalence of sense (Griffiths, 2006). It refers to words that mean the same or show semantic resemblance to one another. Words in synonymous pairs can replace each other in sentences with no change of the literal meaning, and therefore, the substitutability test is used to determine whether or not words are synonyms. This is the general concept of synonymy but when it is deeply investigated, some synonyms seem to be so similar in meaning that they cannot be differentiated either denotatively or connotatively while others are 
not that much close. Farghal $(1998$, p. 117) stated that "synonyms could be placed on a scale of synonymity where different degrees of semantic overlap could emerge". Cruse (2000) pointed out that this scale consists of absolute synonymy, cognitive synonymy and near-synonymy.

Absolute synonymy shows complete identity of all meanings of two or more lexemes in all contexts. For example, the words couch, sofa and settee denote the same object and may be interchangeable in different contexts, thus, can be considered absolute synonyms. However, it is rare for two words to have exactly the same meaning in any possible context and that is why it is generally accepted that absolute synonymy is impossible or non-existent (Bloomfield, 1935; Bolinger, 1968; Lyons, 1996; Taylor, 2003 among others).

As there are no two words with absolutely the same meaning, cognitive synonyms are what most semanticists would regard as cases of synonymy. Lyons (1996) stated that many theories of semantics would restrict the notion of synonymy to this type. Cognitive Synonymy refers to words with the same referent but differ in respect of their evaluative/connotative meaning. Radford, Atkinson, Britain, Clahsen, and Spencer (2009) pointed out that we can investigate cognitive synonymy in terms of entailment. For example, the words mother $/ \mathrm{mom} / \mathrm{mum}$ seems to have the same meaning as they all refer to the female parent of a child or animal. A sentence like $m y$ mother's name is Jane entails the sentence my mum's name is Jane, and they both guarantee the truth of my mom's name is Jane provided that it is the same person at the same point in time. However, from a sociolinguistic perspective, there are differences between these words. Mom and mum are informal, and mom is used by speakers of North American English while mum is used by speakers of British English. Although these words have the same literal meaning, they belong to different registers or dialects.

Some lexical items share aspects of meaning but differ in others and are considered more or less similar. They impart sentences with different propositional content and can contrast in certain contexts. These are known as near-synonyms or plesionyms and can be distinguished from cognitive synonyms by the fact that "they yield sentences with different truth conditions: two sentences which differ only in respect of plesionyms in parallel syntactic positions are not mutually entailing, although if the lexical items are in hyponymous relation, there may be unilateral entailment. There is always one member of a plesionymous pair, which is possible to assert, without paradox, while simultaneously denying the other member" (Cruse, 1986, p. 285). For example, the words kill and murder are considered near-synonyms because their senses overlap to a great degree, but not completely. We can deny one and affirm the other as in the sentence "he was killed, but I can assure you he was NOT murdered, madam" (Cruse, 2000, p. 159).

Synonymy may be important in studying the cross-linguistic differences and similarities between different languages by using a linguistically grounded mapping that has access to parameter settings in the lexicon. Establishing correspondences between words of different languages is essential to multilingual knowledge processing (Huang, Tseng, \& Tsai, 2002). The translation equivalents in a pair of languages stand in a lexical semantic relation since they represent a case of synonymy such as the English 'apple' and the Arabic 'تفاحة'. However, "since no two languages are identical either in meanings given or in phrases and sentences, then there can be no absolute correspondence between languages" (Nida, 1964, p. 156). Therefore, translators face many problems in conveying the intended semantic message and finding the exact lexical equivalents in the target language, in addition to the cultural aspects that they need to overcome in the source language. These problems become much more complicated when it comes to translating religious books into a foreign language as translators are required to transfer not only the surface meaning of words but also the intended message behind them. What makes the task even more difficult is that many words have more than one meaning and some may be interpreted differently by different translators. In addition, many words have very similar meanings but upon deeper semantic and contextual analysis, they convey different meanings .

Among the religious books that received a great attention by linguists for its unique type of discourse is the Holy Qur'an. The fact that a large number of Muslims do not know Arabic and use translation as a means to understand the meanings and messages of the Holy Qur'an makes it indispensible to render this universal text into other languages in general, and today's lingua franca, English, in particular, especially that it is becoming the most influential language for international discourse (Graddol, 2006). The growing Muslim communities in English-speaking countries and the increasing academic interest in studying the Holy Qur'an, sometimes for political and strategic purposes, entails that considerable attention be paid to the way these translations are done (Mohammed, 2005). On the other hand, despite the realization of the necessity for the translation of the Holy Qur'an, Muslim scholars agree that it cannot be more than an approximate interpretation that enables non-Arabic speakers to understand the original text.

The Holy Qur'an has features that are difficult for translators to transfer into another language, and they face 
problems in conveying the eloquent meanings of the verses, especially the lexical items. From a wide variety of these problems is synonymy.

This study focuses mainly on rendering the meanings of near-synonyms in the English translations of the Holy Qur'an. Al-Munjed (1997) stated that synonymy had been widely investigated throughout history in the studies conducted by various Muslim scholars in order to interpret the meanings of the Holy Qur'an. Although there are conflicting views regarding synonymy with some affirming its existence while others refute it, the question of whether or not the Holy Qur'an uses synonymy lies beyond the scope of this study. It deals basically with words that seem to represent a case of near-synonymy. Near-synonyms are plentiful in the Qur'an, but every word of each pair has a particular function at various levels of meaning or usage in a certain context (Al-Sowaidi, 2011). Therefore, many translators fail to capture the shades of overlapping denotations or connotations of the synonymous words, and a deep understanding of the verse context is needed to differentiate their meanings. The present study is, therefore, an attempt to explore the strategies used by different Qur'an translators in rendering these pairs of synonyms into English, and to find out which translations could be more proper than others.

\section{Statement of the Problem, Objectives, Questions}

The Holy Qur'an has many English translations that differ in the choice of lexis and the style and structure of sentences. A cursory glance at these translations shows that the translators encountered several difficulties while translating near-synonyms since repetition is much less welcome in the English language. Dickens, Hervey, Higgins, and Dickins (2002, p. 112) stated: "As with lexical item repetition, it will be seen that English tends to go for variation in phrases, while Arabic frequently prefers repetition". This aspect of style can cause translation problems for translators, and therefore, hinder the proper rendering of the meanings conveyed by the verses of the Holy Qur'an. As a result, there is a pressing need to examine the strategies that translators adopt while translating synonymous pairs, and also to evaluate their English renderings in the different published translations. The present study is an attempt towards this end.

This study aims to :

1) compare and contrast how the root-sharing near-synonyms اسطاع/استطاع that occurred within the same verse were rendered in five well-known English translations of the Qur'an, namely, Pickthall (1930), Ali (1982), Arberry (1996), Abdel Haleem (2004), and Al-Hilali and Khan (2018) in order to find out which is more properly translated.

2) investigate the strategies that were adopted to overcome the difficulties of approaching the selected near-synonyms within the same verse in the selected translations of the Holy Qur'an.

3) find how consistent the translators were in rendering the meaning of the selected words when they occurred as a member of the synonymous pair in the same verse and elsewhere.

The current study aims at answering the following questions:

1) How do the lexical choices of the translated root-sharing near-synonyms اسطاع/استطاعinto English differ among the selected translations of the Holy Qur'an?

2) What are the strategies that these translations adopt to render these near-synonyms into English?

3) Based on the Holy Qur'an exegeses and the Arabic-Arabic dictionaries, how accurate are the selected translations with regard to rendering near-synonymy into English ?

4) To what extent could translators maintain consistency in translating these words when they occurred as members of synonymous pairs within the same verse and elsewhere.

\section{Literature Review}

It is widely acknowledged that no one can provide a perfect translation of the Holy Qur'an since it is the very Word of Allah. Therefore, the job of the translators may be limited as full understanding of the intended meaning of the Quran remains beyond the ability of human beings. Translators agree that rendering the Holy Qur'an into a foreign language is only about transmitting the meanings of texts into the target language, since literal translation is unconceivable and cannot deliver the intended message behind the verses (Zarkani, 1945). Moreover, many words in the Holy Qur'an have more than one meaning, and therefore, the translators must be careful when they choose the right equivalent of these words.

The eloquence and rhetoric of the Qur'an is incomparable in that it is considered to be the model of Arabic linguistic excellence (Ubaidat, 1990). It employs many stylistic, linguistic and rhetorical features that may impose even more challenges on the translators, especially when it comes to literary devices such as metaphor, 
irony, polysemy, metonymy, simile, synonymy and homonymy. Therefore, translators should not ignore such semantic features when attempting to translate the Qur'anic text. AlMisned (2001) investigated how translators interpret metaphors in Chapter Al-Hajj and found that the best translation is the one that explains or paraphrases the meaning to be readable and comprehensive for the target readers.

The problematic issues in translating the Holy Qur'an have attracted the attention of linguists and translation theorists alike over the years. Abdellah (2010) investigated the accuracy of translating near synonyms in the Qur'an based on a context-analysis model. He selected the words ' مطر' and ' غيث' in five translations of the Holy Qur'an. The results revealed that some translations are better than others in conveying the message expressed in the pair of near-Synonyms 'ghayth' and 'maţar'.

Similarly, Al-Sowaidi (2011) examined the problems that translators of the Holy Qur'an face while translating near-synonyms from Arabic into English with reference to two translations namely, Yusuf Ali and T. B. Irving. The study concluded that the selected translations failed to maintain the depth of the Qur'anic message as well as the connotative shades of meanings of the original expression.

Likewise, Al-Jabri (2012) examined the problematic nature of synonymy in relation to translation. The researcher used the componential analysis to evaluate the semantic aspects of the synonymous lexical items according to their context in the verses of the Holy Qur'an. The study revealed that there are differences among the related lexical items which must be considered by translators. However, the examined translations proved to be inaccurate in terms of selecting the lexical items for the related words, and are usually translated into more general words in the target language.

In the same vein, Al-Omari and Abu-Melhim (2014) investigated the phenomenon of synonymy in both English and Arabic languages with special reference to the Holy Qur'an. The aim of the study was to compare and contrast the use of synonymy in both languages by highlighting different theories and opinions offered by scholars and linguists. The study revealed that absolute synonyms in the Holy Qur'an do not exist at all.

Al-Ghazălli and Al-Musawi (2015) studied the translation accuracy of Qur'anic synonymy into English. The results proved that the frequency of the inaccurate translations of lexical synonyms found in Qur'anic texts is very high. Moreover, Arabic-speaking Muslim translators outperformed the others in producing more accurate translations which can be attributed to their linguistic competence and Islamic background.

Abdul-Ghafour, Awal, Zainudin, and Aladdin (2017) investigated the nuances that exist between three pairs of near-synonyms in the Holy Qur'an and how they were reflected in two English translations of the Qur'an. The findings of the study revealed that there are differences between the pairs of the selected near-synonyms in terms of denotative and expressive meaning, and they are not reflected in the English translations.

Hussein and Hameed (2017) analyzed synonyms in the Holy Qur'an to prove that there is no identical meaning between lexical items. The study concluded that synonyms may take various forms with the nominal being the most frequent, followed by the clausal, phrasal and finally verbal. The study also found that there are no identical synonyms in almost all languages, including Arabic.

\section{Methodology}

The present study is qualitative in nature. It aims at finding to what extent the translated root-sharing near-synonyms اسطاع/استطاع are accurate when they occurred in the same verse. It uses a descriptive method that is based on the componential analysis which is considered a useful approach in the study of meaning. In this type of analysis, the word is believed to be built up of smaller components of meaning that form a complicated structure (Crystal, 1987, p. 104). In componential analysis, the meaning of a words is described through sets of semantic features, and the contrasts of those features are usually made in terms of binary rules with $(+)$ or $(-)$ showing the presence or absence of features respectively (Saeed, 2004, p. 260) .

The data is collected from two sources. The first is the Qur'anic Arabic Corpus (Note 1) which provides seven parallel translations in English for each verse in the Holy Qur'an including Sahih International, Pickthall, Yusuf Ali, Shakir, Sarwar, Arberry, and Al-Hilali and Khan. The other source for data collection is the translation of Abdel-Haleem (Note 2) as it is not available on the Qur'anic Arabic Corpus website, but the researcher has access to it being readily available on the internet.

The procedures follow as:

1) The researcher quoted the Arabic Qur'anic verse in which the selected near-synonyms occur. The selected five translations of the verse are presented in tabular forms and the near-synonyms are given special focus by writing them in bold letters. 
2) The Arabic near-synonyms under investigation are looked up in the selected exegeses and Arabic-Arabic dictionaries to find the minor differences between them. The data is also arranged in tables.

3) The near-synonyms are then analyzed into their semantic components that make up the basic concept of each word under study.

4) The selected English equivalents given by the five translators are then looked up in English-English dictionaries to find how accurate they were in terms of matching the basic components of the Arabic words with those of their English counterparts.

5) All occurrences of the near-synonymous words under investigation are then arranged in tables with their English equivalents as given by the five translators. This is intended to find how consistent they were in rendering these words when they occurred as part of synonymous pairs and elsewhere.

\section{Data Analysis and Discussion}

\subsection{Lexical Choice and Translation Strategies}

The synonymous pair اسطاع/ استطاع occurred in the same verse in Chapter (18) sūrat 1-kahf (The Cave). The translators under investigation rendered them as follows.

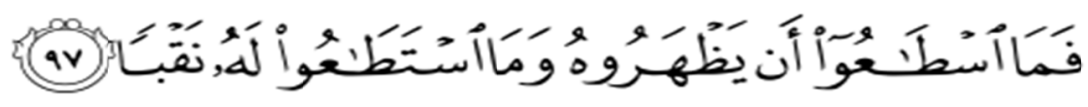

Pickthall: And (Gog and Magog) were not able to surmount, nor could they pierce (it).

Yusuf Ali: Thus, were they made powerless to scale it or to dig through it.

Arberry: So, they were unable either to scale it or pierce it.

Al-Hilali\& Khan: So, they [Ya'juj and Ma'juj (Gog and Magog)] were made powerless to scale it or dig through it.

Abdel-Haleem: Their enemies could not scale the barrier, nor could they pierce it.

The different translations of the near-synonyms are arranged in Table 1

Table 1. The translations of the words اسطاع/ استطاعin the five translations

\begin{tabular}{|c|c|c|}
\hline \multicolumn{3}{|c|}{ 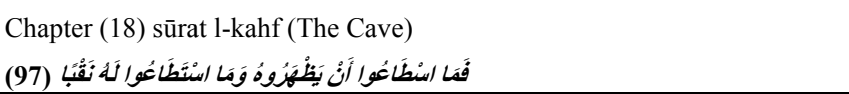 } \\
\hline Word/Translator & اسنتَطَاعَوُوا & اسنْطَاعُوا \\
\hline Pickthall & not able to & nor could \\
\hline Yusuf Ali & powerless & \\
\hline Al-Hilali\& Khan & powerless & \\
\hline Arberry & unable & \\
\hline Abdel-Haleem & could not & nor could \\
\hline
\end{tabular}

Table 1 shows the different lexical choices that the translators opted for when they rendered the words اسطاع/ استطاع|into English. Pickthall used two different English equivalents being able to and could. This may be viewed as a good technique since he avoided repetition as it is not a preferable strategy in the English language. Yusuf Ali, Al-Hilali \& Khan, and Arberry resorted to deletion of one of the near-synonymous words. The former two used powerless while the latter used unable. This strategy goes in line with the English sentence structure and does not involve using two words with the similar meaning successively. However, this raises questions over the faithfulness to the original text, especially that it is the word of Allah. Abdel-Haleem used the word could twice to refer to both near-synonyms. This structure may be criticized as being weak as it involves repeating the same word in the same sentence. However, it seems more appropriate to use two words, whether same or different, to translate this pair of near-synonyms as each must have been intended for a specific purpose.

\subsection{Accuracy of the English Equivalents of اسطاع/ استطاع}

According to the Arabic-Arabic dictionaries like Lisan Al-Arab (Ibn Mandhūr, 1988) and the Lexicon of the Modern Arabic Language (Umar, 2008), اسطاع/ استطاع are not two seperate words. اسطاع ع being the least used word, is considered a variation of the word استطاع/ أسناع. They have the same meaningbut differ in their pronunciation 
since استطاع has an additional consonant. This makes to pronounce as it does not involve two sounds, $/ ت /$ and $/ /$ /produced from very close places of articulation occurring in sequenced syllables. Both sounds are pronounced with the tip of the tongue against the hard palate behind the front teeth, but in $/ b /$, the tongue is raised.

However, اسطاع/ استطاع were used in the Holy Qur'an distinctively although one is considered a different variation of the other, and hence, must have the same meaning. According to the Qur'anic exegeses, the words involve a slight difference in meaning in terms of the effort exerted. Table 2 below includes the interpretation of the words اسطاع/ استطاع in two commentaries.

Table 2. Differences between اسطاع/استطاع in two Qur'anic exegeses

\begin{tabular}{lll}
\hline Word & Ibn Kathīr (2009) & AlGhirnati (1971) \\
\hline \multirow{2}{*}{ اسطاع } & $\begin{array}{l}\text { This word is simpler in terms of pronunciation } \\
\text { and is used to indicate a simpler work. }\end{array}$ & $\begin{array}{l}\text { The word is a shorter form of } \\
\text { effort. }\end{array}$ \\
& $\begin{array}{l}\text { The additional sound 't' indicates additional } \\
\text { effort. So, this word is used to refer to a harder } \\
\text { work. }\end{array}$ & $\begin{array}{l}\text { Using this word with all its sounds without any omission } \\
\text { makes the job harder and uneasy to be performed. }\end{array}$ \\
&
\end{tabular}

The meaning of the words اسطاع/ استطاع as the consulted exegeses proved is highly dependent on the context. There is a rule in the Arabic language that says "increased letters in the structure of a word intensifies its meaning" (Alfathi, 2009). Consequently, the word سطاع/has fewer sounds, and therefore, signifies less effort. On the other hand, the word استطاع|is the most frequently used form, and using it fully without deleting any of its sounds implies a harder work. Taking the context of both words into consideration, سطاع was used with the attempt to climb the top of the dam, whereas استطاع was used with the attempt to dig through it. When the effort involved in both actions is compared, piercing the dam is much harder than climbing it, and hence, the word with more letters was used to refer to it. The context of the verse was intended to mean that not only were they unable to do work that involves difficulty, but also they could not perform an action that requires no significant effort.

Ibnu Asyur (1997) stated that it is not easy in Arabic to pronounce the sounds ' $'$ ' and ' $\boldsymbol{b}$ ' successively as they have the same place of articulation. This emphasizes that the word سنطاع|needs more effort to be pronounced, and consequently indicates a harder work. He added that using two different words is intended for rhetorical purposes since repeating the same word within the same verse is considered a demerit of style and affects the eloquence of the text.

In light of what was mentioned above, it is emphasized that the meaning of the Qur'anic terms must be looked up in different sources starting with the exegeses and moving to the Arabic dictionaries and books, especially when there are sensitive cases as near-synonymy, since the minor differences in meaning are not always stated in all references. As the componential analysis is considered a useful way in determining the slight differences between words in general, and synonyms in particular, اسطاع/ استطاعare analyzed in terms of their semantic features in Table 3 based on the meanings provided by the Qur'anic exegeses.

Table 3. Componential analysis of اسطاع/ استطاع

\begin{tabular}{lllll}
\hline Investigated Lexical Items & \multicolumn{5}{l}{ The Semantic Components } \\
\cline { 2 - 5 } & Ability & Possibility/Opportunity & Having Power & Difficulty \\
\hline اسطyyy & + & + & + & - \\
\hline استطاع & + & + & + & + \\
\hline
\end{tabular}

Table 3 shows that there is no difference between the words اسطاع/ استطاع except for the difficulty involved in the action. Although the consulted dictionaries stated that these words can be used interchangeably, the componential analysis proves that اسطاع is used to refer to an ability that does not require much effort unlike استطاع. This difference may not be familiar to many people as the word اسطاع is very uncommon in the Arabic language. Even in the Holy Qur'an, it was mentioned only twice.

Not only the investigated Arabic words are analyzed in terms of their components, but also the English equivalents selected by the translators. This is intended to find if the translation properly reflects the differences between اسطاع/ اسنطاع. It must be noted here that in the original text, the Qur'anic terms were negated. It was easy in Arabic to detach the negative particle as it stands by itself. This also applies to English in some cases 
when the particle is like not, never, neither, nor, etc. or also when it is a prefix such as un-. When negation is the result of adding a suffix, detaching it will give a different grammatical category of the word, and hence a different meaning as in the case of powerless. But the components of words are better given here in their affirmative form. Therefore, Table 4 shows the componential analysis of the English words given by the five translators without negation. The semantic features given are based on the words definition in different online English-English dictionaries (Oxford (Note 3), Cambridge (Note 4), definitions.net (Note 5)).

Table 4. Componential analysis of the English equivalents of اسطاع/ استطاع

\begin{tabular}{lllll}
\hline English Equivalent & \multicolumn{5}{l}{ The Semantic Components } & past action \\
\cline { 2 - 5 } & ability & possibility/opportunity & power or strength & + \\
\hline able & + & + & + & + \\
could & + & + & + & + \\
(having) power & + & + & + & \\
\hline
\end{tabular}

Table 4 indicates that the English words do not show any difference in terms of their usage, and can be used interchangeably. This stresses the fact that some Qur'anic terms are untranslatable and finding an equivalent seems to be impossible. The inadequacy of translation in such cases is not attributed to the translators. They did a commendable effort trying to deliver the intended meaning, but the problem arises when the target language lacks adequate equivalents to the words that are used to present the eloquent and rhetorical features in the Holy Qur'an. The main point that translators may be blamed for is that they should have included the difference between such words as a footnote or explanation between brackets so that the English reader of the Holy Qur'an will realize that repetition of words that represent synonymy is meaningful and intended for a specific purpose.

\subsection{Consistency of the English Equivalents of /سطاع/ استطاع Within the Same Verse and Elsewhere}

All different occurrences of the near-synonyms اسطاع/ استطاع are arranged in tables with their translations in order to find to what extent could the five translators maintain consistency in their renderings of these words when they occurred as members of synonymous pairs and elsewhere. Table 5 shows all occurrences of اسطاع.

Table 5. All occurrences of اسطاع in the Holy Qur'an with their translations

\begin{tabular}{|c|c|c|c|c|c|c|c|c|}
\hline اسطاع & & & & & & & & \\
\hline $\begin{array}{l}\text { Chapter } \\
18 \\
18\end{array}$ & $\begin{array}{l}\text { Verse } \\
82 \\
97\end{array}$ & $\begin{array}{l}\text { order } \\
33 \\
6\end{array}$ & $\begin{array}{l}\text { Word } \\
\text { tasți } \\
\text { is'tatâa } \bar{u}\end{array}$ & $\begin{array}{l}\text { Pickthall } \\
\text { couldst not } \\
\text { not able to }\end{array}$ & $\begin{array}{l}\text { Yusuf Ali } \\
\text { unable to } \\
\text { powerless }\end{array}$ & $\begin{array}{l}\text { Al-Hilali \& Khan } \\
\text { couldn't } \\
\text { powerless }\end{array}$ & $\begin{array}{l}\text { Arberry } \\
\text { couldst not } \\
\text { unable }\end{array}$ & $\begin{array}{l}\text { Abdel-Haleem } \\
\text { could not } \\
\text { could not }\end{array}$ \\
\hline
\end{tabular}

This table shows that the word اسطاع is not at all frequent in the Holy Qur'an and was used only twice in Chapter (18) sūrat l-kahf (The Cave). In verse (82), only اسطاع was used and was meant here for a specific reason. In the Qur'anic narrative in this Chapter, Moses meets Al-Khidr and asks to accompany him to be able to learn from his knowledge. Al-Khidr answers that Moses will not be patient and the present form of the word استطاع is used

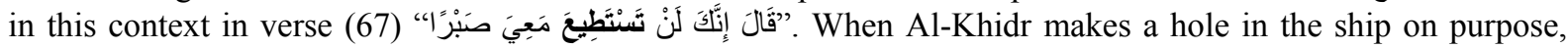
Moses blames him for performing a grievous act. Al-Khidr answers that he told him that he will not be patient as

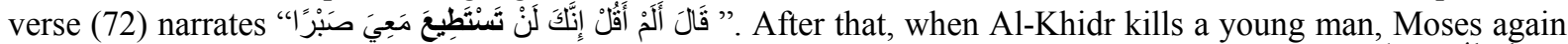

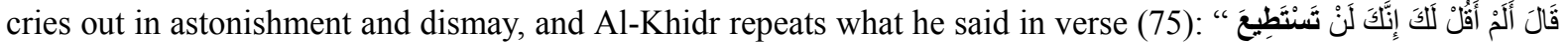
"مَعِيَ صَبْرًا again Moses is amazed and asks why he didn't ask for some recompense for it. This time, Al-Khidr says that this shall be separation between them; and will inform Moses of the significance of what he could not have patience

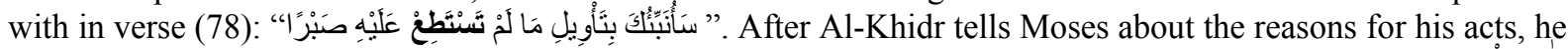

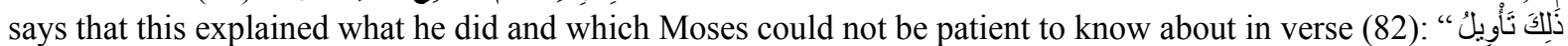
"مَا لَمْ تَنْطِعْ عَلَيْهِ صَبْرًا involved in the action, this Qur'anic narrative explains why in verses (67), (72), (75) and (78) the word was used. It was extremely hard for Moses to be patient while seeing Al-Khidr performing acts that were not justifiable and seemed violent. However, when the reasons behind the acts were clarified, the word اسطاع was used to imply that the hardship of being ignorant was eased.

In verse (97), اسطاع استطاعis present alongside. Looking at the table again, it is noted that four of the selected translators, namely, Pickthall, Yusuf Ali, Al-Hilali \& Khan, and Arberry, did not maintain consistency in their 
renderings of the word اسطاعWhen it occurred with ستطاعin the same verse and its other occurrence. Each of them used two different equivalents each time the word was used. However, Abdel-Haleem used only one-word being could for both occurrences, making him the most consistent in terms of translating the word اسطاع.

The researchers also examined all occurrences of the word استطاع with their renderings in the five translations under study. The translations of all occurrences prove that none of the selected translators was consistent in rendering the word استطاعinto English, and their lexical choice varied a lot even when the word occurred in exactly the same context. In Chapter (18) sūrat l-kahf (The Cave), the word استطاعloccurred four times in four verses within the same linguistic context. The full verses are shown below:

\begin{tabular}{|c|c|}
\hline (18:67:4) tastațī'a & 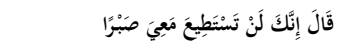 \\
\hline (18:72:6) tastațía & 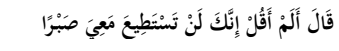 \\
\hline (18:75:7) tastațīa & 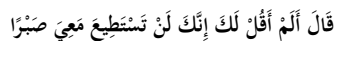 \\
\hline (18:78:10) tastați & 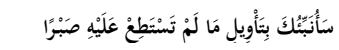 \\
\hline
\end{tabular}

None of the translators tended to keep one translation for the different occurrences of the word they are surrounded with exactly the same words. Their choices seem to be unjustified and do not follow a specific strategy except for Abdel-Haleem. He used not be able and never be able when the tense of the verb was

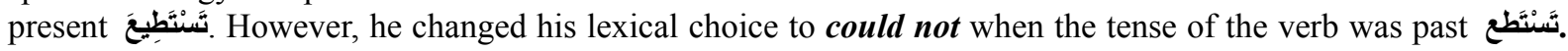
This again stresses that Abdel-Haleem pays much attention to consistency than the other translators do.

Since there is a great variation in the English words used as equivalents for استطاع, Table 6 below shows percentages of each used word by each translator to the overall total of occurrences.

Table 6. Percentages of each used word by the translator to the overall total of occurrences

\begin{tabular}{llllll}
\hline English Equivalent & Pickthall & Yusuf Ali & Arberry & Al-Hilali \& Khan & Abdel-Haleem \\
\hline Different forms of able & 11 & 13 & 22 & 11 & 8 \\
Percentage \% & $27.5 \%$ & $32.5 \%$ & $55 \%$ & $27.5 \%$ & $20 \%$ \\
Different forms of $\boldsymbol{c a n}$ & 17 & 15 & 10 & 20 & 16 \\
Percentage \% & $42.5 \%$ & $37.5 \%$ & $25 \%$ & $50 \%$ & $40 \%$ \\
Different forms of could & 6 & 2 & 5 & 3 & 7 \\
Percentage \% & $15 \%$ & $5 \%$ & $12.5 \%$ & $7.5 \%$ & $17.5 \%$ \\
Different forms of power & 6 & 6 & 2 & 5 & 4 \\
Percentage \% & $15 \%$ & $15 \%$ & $5 \%$ & $12.5 \%$ & $10 \%$ \\
Different forms of means & $\varnothing$ & 2 & $\varnothing$ & 1 & 3 \\
Percentage \% & $0 \%$ & $5 \%$ & $0 \%$ & $2.5 \%$ & $7.5 \%$ \\
Others & $\varnothing$ & 2 & 1 & $\varnothing$ & 2 \\
Percentage \% & $0 \%$ & $5 \%$ & $2.5 \%$ & $0 \%$ & $5 \%$ \\
Total & 40 & 40 & 40 & 40 & 40 \\
\hline
\end{tabular}

Table 6 proves that the English equivalent that was most frequently used for استطاع by Pickthall, Yusuf Ali, Al-Hilali \& Khan, and Abdel-Haleem is can with its different forms, old English, affirmative, or attached to a negative particle. However, Arberry tended to use different forms of able most often with $55 \%$ of the number of occurrences. Can was the second most frequent choice for Arberry while it was able for the other translators. Although Yusuf Ali used can more than able, the difference in use was slight with the former scored 37.5\% and the latter $32.5 \%$. When it comes to the other translators, can was almost used twice as many as able, which indicates a greater prevalence of its use. The third preferable lexical choice for Arberry and Abdel-Haleem was could though it did not score as high as can and able with percentages of $12.5 \%$ and $17.5 \%$ respectively. Yusuf Ali and Al-Hilali \& Khan, however, used different forms of the word power more often than could scoring $15 \%$ and $12.5 \%$ respectively. Pickthall showed no preference for using one of the words could or power over the other as they both scored $15 \%$ of the total occurrences. With regard to the other lexical choices, they were limitedly used by all the translators. In general, it can be said that the main two equivalents of together had the highest share of the overall percentage of all different occurrences.

\section{Conclusion}

The study concluded that the translators varied their lexical choices when they translated the words اسطاع/ استطاع Ento English without clear understanding of their meanings. This may be attributed to the fact that 
repeating words of similar meaning in the same sentence may not be welcomed in the English language. However, when it comes to the Arabic language, and specifically the Holy Qur'an, the case is different. The Holy Qur'an exhibits a unique beauty of the way words are put together, and words of similar meaning are not present in the verses without significance. This stresses that leaving one of the near-synonymous words out is also not the right strategy to follow as this will affect the intended message of the verse. All this proves that some Qur'anic terms are untranslatable and cannot be rendered into another languages. Therefore, it is recommended that translators include the slight differences between the words between brackets or as footnotes in order to acknowledge the non-Arab readers that repetition of the words was not haphazard but intended for specific purposes.

\section{References}

Abdel, H. M. (2004). The Quran. Oxford: Oxford University Press.

Abdellah, A. (2010). Translations of Near-Synonyms in the Qur'an: A Context-Based Analysis. MA Thesis.

Abdul-Ghafour, A.-Q. K. M., Awal, N. M., Zainudin, I. S., \& Aladdin, A. (2017). Meanings of Near-Synonyms and Their Translation Issues in the Holy Qur'ān. GEMA Online ${ }^{\circledR}$ Journal of Language Studies, 17(4). https://doi.org/10.17576/gema-2017-1704-17

Al-Ghazălli, M. F., \& Al-Musawi, A. J. (2015). Translation Assessment of Qurănic Lexical Synonymy into English. International Journal of English Langue and Linguistics Research, 3(2), 28-45. https://doi.org/10.5430/elr.v3n2p33

Al-Hilali, M., \& Khan, M. (2018). Translation of the Meanings of the Noble Quran in the English Language.

Al-Jabri, S. (2012). Lexical Synonyms in the Holy Qur'an and their Translations: A Case Study. International Journal of Arabic-English Studies (IJAES), 13, 7-22.

Al-Munjed, M. (1997). Altraduf fi Al-Qur'an Al-Kareem "Synonymy in the Holy Qur'an between theory and practice”. Damascus, Syria: Dar Al-Fiker Publishing.

Al-Omari, S. K., \& Abu-Melhim, A.-R. H. (2014). Synonymy in English and Arabic with reference to the Holy Qur'an: a contrastive study. Theory Practice in Language Studies, 4(12), 2619. https://doi.org/10.4304/tpls.4.12.2619-2626

Al-Sowaidi, B. (2011). Textuality in near-synonyms translations of the Holy Qur'än into English. University of the Western Cape.

Alfathi, M. T. Y. (2009). The Ambiguity of the increasing of form and its pointing on the increasing of content Practical study on (س (سوف) (in the Glorious Quran. Journal of College Basic Education Researches, $8(4), 178-207$.

AlGhirnati, I. a.-Z. (1971). Milak Al-Ta'weel “Angel of Interpretation”. Beirut: Dar AlKutub Al'ilmiyyah.

Ali, A. (1982). Translation of the Holy Qur'an. Lahore: Muhammad Ashraf Publisher.

AlMisned, O. A. (2001). Metaphor in the Qur'an: an assessment of three English translations of Suurat Al-Hajj. Durham University.

Arberry, A. J. (1996). The Koran interpreted: A translation. New York City: Simon and Schuster.

Bloomfield, L. (1935). Language. London Allen \& Unwin.

Bolinger, D. (1968). Entailment and the Meaning of Structures. Glossa: An International Journal of Linguistics, 2(2), 119.

Carroll, D. W. (1998). Psychology of language (3rd ed.). Pacific Grove, Calif: Brooks/Cole Pub.

Cruse, D. A. (1986). Lexical semantics. New York: Cambridge Cambridge University Press.

Cruse, D. A. (2000). Meaning in language: An introduction to semantics and pragmatics. Oxford OUP.

Crystal, D. (1987). The Cambridge encyclopedia of language (Vol. 2). Cambridge: Cambridge University Press

Dickens, J., Hervey, S., Higgins, I., \& Dickins, J. (2002). Thinking Arabic Translation. London and New York: Routledge.

Farghal, M. (1998). Vocabulary development and lexical relations: a coursebook. Dar Al-Hilal for translation.

Graddol, D. (2006). English Next. British Council. UK: Latimer Trend \& Company Ltd.

Griffiths, P. (2006). An introduction to English semantics and pragmatics. Edinburgh: Edinburgh University Press. 
Huang, C., Tseng, I., \& Tsai, D. (2002). Translating lexical semantic relations: The first step towards multilingual WordNets. Paper presented at the Proceedings of the 2002 workshop on Building and using semantic networks-Volume 11. https://doi.org/10.3115/1118735.1118741

Hussein, A. M., \& Hameed, N. S. (2017). Investigating Synonyms in the Glorious Qur'an. Swift Journal of Social Sciences and Humanity, 3(1), 001-007.

Ibn Kathīr, I. (2009). Tafsīr Ibn Kathīr. London: MSA Publication Limited.

Ibn Mandhūr, M. (1988). Lisan al-arab (Vol. 5). Beirut: Dar Al-Kutub al-Ilmiyyah.

Ibnu'Asyur, M. (1997). Tafsir alTahrir wa al-Tanwir. Tunisia Dar Shuhnun li al-Nasyr wa al-Tauzi'.

Lyons, J. (1996). Semantics. Cambridge; New York: Cambridge University Press.

Mohammed, K. (2005). Assessing English translations of the Qur'an. Middle East Quarterly, 12(2), 58-71.

Murphy, L. (2010). Semantic relations and the lexicon: Antonymy, synonymy and other paradigms. Cambridge University Press.

Nida, E. A. (1964). Toward a science of translating: with special reference to principles and procedures involved in Bible translating. Brill Archive.

Paradis, C. (2012). Lexical semantics. The Encyclopedia of Applied Linguistics. https://doi.org/10.1002/9781405198431.wbeal0695

Pickthall, M. M. (1930). Holy Quran: English translation. Begum Aisha Bawary Wakf.

Radford, A., Atkinson, M., Britain, D., Clahsen, H., \& Spencer, A. (2009). Linguistics: an introduction. Cambridge University Press. https://doi.org/10.1017/CBO9780511841613

Saeed, J. (2004). Semantics (Vol. 2). Cambridge, Mass: Blackwell Publishers.

Taylor, J. R. (2003). Near synonyms as co-extensive categories: 'high' and 'tall' revisited. Language Sciences, 25(3), 263-284. https://doi.org/10.1016/S0388-0001(02)00018-9

Ubaidat, M. (1990). DirasaatfL 'L'uloom al-Qur'an. Jordan: Dar Ammaar.

Yule, G. (2010). The study of language: an introduction. New York; Cambridge: Cambridge University Press. https://doi.org/10.1017/CBO9780511757754

Zarkani, M. A. A. (1945). Manahel al-arfan fi oloom al-Quran. Cario, Egypt: Dar Ihya'a AlKutub AlArabiyyah.

\section{Notes}

Note 1.https://corpus.quran.com

Note 2. https://www.researchgate.net/.../the_QURAN-abdel-haleem-ebook-english.pdf

Note 3. https://www.oxfordadvancedlearnersdictionary.com

Note 4. https://dictionary.cambridge.org

Note 5. https://www.definitions.net

\section{Copyrights}

Copyright for this article is retained by the author, with first publication rights granted to the journal.

This is an open-access article distributed under the terms and conditions of the Creative Commons Attribution license (http://creativecommons.org/licenses/by/4.0/). 